\title{
Relations between usage patterns of performance indicators and the role of individual firms in fresh fruit agri-food supply chains
}

Antonio Cunha Callado and Lisa Jack

\begin{abstract}
Purpose

This paper reports the use of performance metrics among 121 Brazilian agribusiness companies, with the aim of helping accountants and academics to understand the actual use of performance metrics in non-integrated supply chains.
\end{abstract}

\section{Design/methodology/approach}

To identify which performance metrics are used among supply chain partners, four independent clusters representing specific supply chain roles (input suppliers, farmers, distributors, and retailers) were formed. Data relating to 49 performance metrics was collected by questionnaire and analysed statistically to isolate common measures.

\section{Findings}

, It was found among suppliers, farmers, distributors, and retailers that the performance metrics for return on investment, responsiveness, and response time to clients are not being used whereas customer satisfaction obtained a usage pattern in all roles in the four groups. Hence, it appears that customer satisfaction rather than financial sustainability is the driver for discussion between supply chain partners.

Research limitations/implications

Although limited to a sample of firms within Brazil, the findings confirm evidence from similar supply chains worldwide. 
Practical implications

These findings suggest that the common metrics approach to measure supply chain performance may be very difficult to achieve in practice and other alternatives should be investigated by management accountants.

\section{Social implications}

A predominance of customer satisfaction metrics to the exclusion of discussions on financial performance between partners in agri-food supply chain has implications for the sustainability of the industry and the ability of accountants and managers to negotiate when faced with increasing input costs.

Originality/value

This contributes to accountants' understanding of how performance measurement works in fragmented supply chains, whereas the majority of the literature is concerned with integrated supply chains.

\section{Keywords}

Performance measurement, fresh fruit supply chain, supply chain performance, balanced scorecard.

\section{Introduction}


A supply chain (SC) can be defined as a network of three or more individual companies through which products flow from primary sources to end consumers (Min, Mentzer \& Ladd, 2007; Elrod, Murray \& Bande, 2013). Co-ordination mechanisms tend to be based on hierarchical or market relationships along the SC structure (Williamson, 1975). Whilst both academics and practitioners have examined performance measurement within SC over several decades (Ganga \& Carpinetti, 2011) there remains very little discussion in the available literature that deals with performance measurement within non-integrated SC. For management accountants concerned with the effectiveness of the management controls and metrics that they introduce into organizations, or monitor and evaluate, knowledge about which financial and non-financial measures are used in practice is necessary for bringing about changes in systems and practices.

Long-term integrated collaborative relations (Chow, Heaver \& Henriksson, 1994; Beamon, 1998; Beamon, 1999; Brewer \& Speh, 2000; Holmberg, 2000; Gunasekaran, Patel \& Tirtiroglu, 2001; Gunasekaran, Patel \& McGaughey, 2004; Chang, 2009) and product quality and service targets (Hofman, 2004; Varma, Wadhwa \& Deshmukh, 2008; Chia, Goh \& Hum, 2009; Akyuz \& Erkan, 2010; Wu \& Chang 2012) are associated with successful SC performance. However, other less integrated or long-term, upstream and downstream business relationships exist throughout different SC (Mentzer et al., 2001). Hann et al. (2003) state that hierarchical relationships in SC should be considered only if markets cannot provide efficient protection against opportunism.

An agri-food supply chain (ASC) is a network of companies that work together to deliver agricultural products to final consumers (Christopher, 2005). The structure of an ASC can be complex, with many entities being included and with numerous interactions 
(Matopoulos, Vlachopoulou, \& Manthou, 2007). Furthermore, several specific roles such as input supplier, producer (or farmer), processor (or manufacturer), distributor (or wholesaler) or retailer can be identified within an ASC (Henson and Reardon, 2005).

Brazil is the world's third largest fruit producer (FAO, 2013) with approximately 20 million tons of fresh fruits produced on 1.1 million hectares throughout the country and the European Union is Brazil's main market consuming over $70 \%$ of Brazilian production (Brazilian Fruit, 2014). The structure of an ASC of fresh fruits from Brazil encompasses input suppliers, producers, distributors and retailers (MAPA, 2007). Almost all fresh fruit ASC is formed by several individual independent companies that do business through spot market transactions from input suppliers to end customers based both efficiency and flexibility (Neves, 2003).

The underlying question in the investigation is whether a balanced set of performance metrics might be used among partners in fresh food supply networks, given the prevalence in the industry of independent business entities and a general lack of integration between supply chain partners. Although, as Jack et al (2012) found in the UK, retailers tend to favour the quality and delivery that come from long term relationships but the prices that come from trading - a situation found in fresh produce supply chains in many countries, including Brazil - there are signs that retailers are seeking to establish more long term partnerships, at least with intermediary businesses, to increase efficiency and reduce overhead costs. It should be a matter of concern to accountants involved in management control, and even more those involved in advising food companies in financial distress, if the performance metrics used do not routinely include finance measures in supply chain negotiations. 
A balanced set of performance metrics might be used between business partners in fresh food supply networks, where a future long term relationship might be envisaged (Zhao, 2002; Park, Lee \& Yoo, 2005; Bigliardi \& Bottani, 2010). If only one or two measures are commonly used by all parties in fresh produce supply chains, this would suggest that significant changes would need to be introduced in longer term relationships to establish a balanced approach. Whether or not a supply chain Balanced Scorecard (BSC) might be effective or desirable, this investigation into the performance measures used across the fresh produce supply network, based on the four dimensions of the BSC as a framework, illuminates current issues in ASC. In particular, these concern perceived problems relating to (low) prices received by suppliers and the dominance of retailers in the industry.

The aim of this paper is to look for similarities and differences in the patterns of use of performance indicators for Brazilian agribusiness companies from fresh fruits ASC, while taking their SC roles into consideration. Our results show that although all dimensions are measured by individual participants in the supply network, only one measure - customer satisfaction - is measured by all. This is significant because it supports other empirical work showing that only customer satisfaction - often relayed as 'on time in full to specification' delivery - is used in negotiations with suppliers. This has potentially detrimental effects on the ability of suppliers to recover costs when input prices rise. A positive effect of a balanced set of metrics could be to ensure that financial measures are included in discussions between supply chain partners, and that price negotiations are more likely to be equitable. 
In addition, the usage patterns of performance indicators change across SCs. These findings suggest that the common metrics approach to measure SC performance may be very difficult to achieve in practice and other alternatives should be investigated. The findings also support evidence from UK ASCs, which show a predominance of customer satisfaction metrics to the exclusion of discussions on financial performance between clusters in ASCs. Although each of the individual companies may consider specific criteria to select a group of relevant performance metrics, all of them will tend to form a balanced set of relevant metrics considering their respective organizational characteristics and managerial needs (Prieto et al., 2006).

The main contribution of this paper is to establish which roles use which performance indicators, and thereby to identify from where the drive for wider use of performance measures between SC partners in a non-integrated SC should come. The necessity for this wider use lies in the security and sustainability of fresh produce SC, where producers and intermediary businesses in ASC are subject to very low margins and the rate of insolvency is seen to be increasing (Oliveira et al., 2014; Pelegrini, Shiki \& Shiki, 2015). The paper also opens a wider discussion on non-integrated SC to complement the existing SC and PM literature based on dyadic partnerships in integrated SC.

\section{Supply Chain Performance Measurement}

There is a significant literature on the effectiveness, or otherwise, of supply networks across the management disciplines. In accounting, there are relevant studies on open book accounting and other management control techniques employed between usually two supply chain partners, but less studies on management accounting and control between several partners or across networks. Supply chain relationships in the food chain have 
been largely discussed in the field of marketing and operations. The literature includes two areas relevant to this study: the extent to which processes are integrated and information is shared; and the development of performance measurement systems within SC, by accountants and other managers.

The level of integration and information sharing is the most relevant to our study. Vachon et al (2009) adopt a transaction cost economics approach to assess the level of co-operative interaction between the organization and its customers as this indicates the extent to which routines can be developed to facilitate strategic alignment. They find that stronger linkages are found in co-operative rather than arm's length interactions. Responsiveness to changes in market movements, and the ability of manufacturers to translate customer requirements through to their own suppliers speedily is found in collaborative rather than arm's length relationships.

Similarly, Schloetzer (2012) finds that where there is less potential for hold-ups in SC, there greater the evidence of process integration and information sharing. The greater the degree of integration and sharing, the more favourable the financial performance for both partners and interestingly, there were also enhancements in other non-financial performance measures. The suggestion is that supply chains relationships work best when processes are integrated and information shared.

Supply network research also tends to consider size and roles in analysing a network's value to users (Afuah, 2013). Afuah (2013) argues that the structure of a network and the conduct of its members are important determinants of its value to members and providers. Using risk based analysis, he demonstrates that a number of factors - feasibility of 
transactions in a network, centrality of members, structural holes and ties between members, and the roles members play - build value. Opportunistic behaviour, reputation and perceptions of trust are also significant.

Also taking a transactional cost approach as Vachon et al (2009) and Schloetzer (2012), along with game theory, Cox and Chicksand (2005) found that although companies are involved in supply chain networks, not all networks are managed efficiently. He contends that mutuality and the search for value capture are not fully commensurable in business relationships, but that, since "win-win" is not an absolute but a variable concept, business relationships can be aligned even when unequal exchange and tension exists between buyers and suppliers. Under some circumstances "win-lose" can be a preferable outcome than "win-win": a situation which both Cox and Chicksand (2007) and Hingley (2005) found in the food retail supply chain.

Several papers set out frameworks for strategic performance measurement systems (SPMS), although these are not all supported by empirical evidence (Estampe et al, 2013). Michele and Manzoni (2010) and Chenall (2005) find that SPMS provide a means of communication within organizations and between an organization and its stakeholders. Flexible use of indicators finds that top managers may enforce certain indicators which leave operational managers feeling that there is some incompleteness in what is being measured and managed. However, frustrations may be diffused if operational managers feel that flexible handling of the control system is possible. Such a system may still be regarded as enabling despite its perceived incompleteness. Incompleteness can explain why designing and implementing PMS in operations is difficult and requires a deliberate and careful approach (Wouters and Wilderon, 2008). 
The remainder of this review of the prior literature considers this last point. The concept of SC relies on the notion that there is some sort interdependence among activities performed by individual companies regardless the presence of market or hierarchical coordinating process among them (Dubois, Hulthén \& Pedersen, 2004).

Market co-ordination is characterized by open market transactions with price-based discussions and adversarial relationships (Spekman, Kamauff \& Myhr, 1998). Hierarchical coordination has been considered as a valid mechanism only when market is not an efficient protection against opportunism (Haan et all, 2003) and few individual companies are actually engaged in full SC hierarchical coordination (Fawcett and Magnan, 2002).

Although elements of co-ordination are present, there is very little discussion in the literature available that deals with the selection of metrics (Beamon, 1998; Beamon, 1999; Chan \& Qi, 2003). Performance metrics selection procedures are, to a certain extent, both subjective (Folan \& Browne, 2005) and uncertain (Lohman, Fortuin \& Wouters., 2004) and the role of individual companies within SCCP may influence their decisions relating to their perspective regarding SC performance measurement (Folan et al., 2005).

Performance measurement of individual companies can be carried out by using a set of individual metrics used to quantify both the efficiency and effectiveness of actions (Neely, Gregory \& Platts, 2005). Each metric should be assigned by the higher level management in search of direct, motivate, and evaluate activities, processes areas, or functions (Melnyk, Stewart \& Swink, 2004). 
Despite the improvements regarding performance measurement methods across SCs, the selection of relevant metrics and the identification of potential problems (Melnyk et al., 2004), the presence of some kind of hierarchy among SC performance metrics still require further investigation (Beamon, 1998).

It is argued that SC performance should consider specific skills and operational excellence from its participants (Morash, 2002), as well as the importance of locating responsibility for performance metrics at the managerial level of the companies within an SC (Kolehmainen, 2010).

The operational aspects of ASCs are distinct from other kinds of SCs (Yu \& Nagurney, 2013). The number of individual companies, the frequency of transactions, the specificities of products and the level of uncertainty are the key aspects considered to identify the most appropriate type of co-ordination to any given ASC (Cabral, 2011) and Individual companies from ASCs have a greater tendency to keep their own identity or autonomy than in of all the SCs (Van der Vorst, 2006).

Within the context of ASCs, performance measurement of individual companies should be assessed considering the perspective from their specific operational roles (Callado, 2015). In interviewing intermediary food SC businesses such as grower-packers and food manufacturers, Jack, Ramon-Jeronimo, and Flores-Lopez (2012) found evidence that performance measures are developed in all areas comparable to the BSC approach although no formal scorecards were found. However, between ASC constituents, and particularly among those downstream, there was a heavy emphasis on customer-related measures in terms of quality and delivery; financial and other measures were discussed 
very rarely. Although these findings relate to an European country, similar results from other countries, such as Brazil, might be found given the nature of the global food industry.

Well-defined performance measurement procedures for SCs can contribute to the improvement of the alignment process throughout the individual companies that form its constituent parts (Folan et. al., 2005; Chenhall, 2005; Lee, Kwon, \& Severance, 2007). Several factors may influence the real contribution that performance measurement can generate for SCs:

- The absence of a clear direction for the SC

- The complexity of performance measurement among the various companies across the $\mathrm{SC}$

- The desire not to share information with other companies

- The difficulty of capturing the performance by customers, products, or specific chains (Lambert \& Pohlen, 2001).

Hence, the main concern of the performance measurement of SCs should be focused on defining the list of metrics that really matter, considering specificities so that the proposed set of metrics should attempt to reflect accurately the desired purposes and skills (Hofmam, 2004).

Some of the main factors associated with the relevance of performance measurement linked to several aspects regarding SCs are as follows:

- The shortage of performance metrics adequate to measure an entire SC

- The need to go beyond the internal performance measurements to capture an overview of the SC 
- The interest in identifying relationships between the performance of individual companies and the performance of an SC as a whole

- The interest in differentiating the performance of an SC to achieve higher levels of competitiveness

- The encouragement of cooperative behavior within an SC (Lambert et al., 2001)

The use of common metrics to measure and evaluate is not considered by others as a valid goal, as this will certainly disregard relevant and representative performance metrics involved in each stage of the SC to the detriment of common metrics possessing different relative significance.

In summary, this study makes a contribution to our understanding of the difficulties in creating integration in non-aligned SC where sharing of information through metrics would be an indicator of the level of integration.

\section{Methodology}

In order to investigate the patterns of use of performance indicators among individual Brazilian agribusiness companies, taking into consideration their role in their fresh fruit ASC, an exploratory survey was carried out based on the use of the BSC approach for supply chain performance (SCP).

Firstly, the following 49 performance indicators presented in Beamon (1998), Rafele (2004), Gunasekaran et al., (2004), and Callado, Mendes, and Callado (2013) were classified among the four perspectives of the BSC as shown below: 
- Financial perspective: profitability, liquidity, revenues by product, revenue per employee, contribution margin, level of indebtedness, return on investment, unit cost, minimising costs, profit maximization, inventory, overall earnings, operation costs;

- Customer perspective: customer satisfaction, customer loyalty, new customers, market share, brand value, profitability by customer, revenue per customer, satisfaction of business partners, delivery time, responsiveness to clients, growth in market share, maximising sales;

- Internal processes perspective: new products, new processes, productivity by business unit, product turnover, after sales, operational cycle, suppliers, waste, flexibility, response time to customers, delay in delivery, response of suppliers, storage time, information/integration of materials;

- Learning and growth perspective: investment in training, technology investment, investment in information system, employee motivation, employee capability, managerial efficiency, employee satisfaction, innovation management, number of complaints, risk management.

Secondly, individual companies were contacted to verify their willingness to participate in this survey and 121 Brazilian agribusiness companies accepted. These companies were clustered to form independent samples according to their specific roles in their SC. Four different SC roles were found among them: input suppliers, farmers, distributors, and retailers. These samples are presented in Table 1.

Table 1: Independent samples from SC roles 
Input suppliers 31

Farmers

Distributors

Retailers

Data collection procedures were similar to Chia et al. (2009) and Lee et al. (2007). The 49 performance indicators were listed in a questionnaire and presented to senior managers who were asked to state which of the indicators were used by their business. Prior to data collection, in order to verify the suitability of the questionnaire, as well as to identify the need of further adjustments, a pretest was carried out.

The criterion used to identify senior managers was the responsibility of making strategic decisions, regardless the name adopted to identify the position. Through three stages Likert scales (Min, Mentzer \& Ladd, 2007), senior managers were also asked to provide information regarding the following:

- Level of education (Papadakis, Lioukas, Chambers, 1998) and professional experience (Teeratansirikool, Siengthai, Badir \& Charoenngam, 2013) of senior managers;

- Size (Hall, 1984), power (Shi, Zhang \& Ru, 2013), and maturity (McCornmack, Ladeira \& Oliveira, 2008) of individual companies;

- Formalization degree of performance measurement procedures. 
Performance indicator usage patterns were identified using two distinct approaches: firstly, usage patterns based on individual performance indicators were identified: secondly, usage patterns were arranged according to the BSC perspectives.

Although the sizes of individual samples were not large enough to enable the use of statistical parametric tests, they were sufficient to set up a data-base (Gunasecaran et al, 2004). Considering the limitations arising from the size of individual samples, three nonparametric statistical tests were used: Spearman rank order correlation test, Fisher's exact test and the Kruskal-Wallis test.

The first statistical test was used to analyze the significance of the correlations between the formalization degree of performance measurement procedures, the number of performance indicators used and the five contingency factors considered. This was achieved by testing the following hypotheses below.

$\mathrm{H}_{0}$ : the variables tested are not statistically related.

$\mathrm{H}_{1 \mathrm{a}}$ : the formalization degree is related to contingency factors.

$\mathrm{H}_{1 b}$ : the formalization degree is related to number of performance indicators.

$\mathrm{H}_{1 \mathrm{c}}$ : the formalization degree is related to contingency factors.

The hypotheses are based on the assumption that formalization is process in which organizations specify rules, responsibilities, processes, and procedures. Formalization degree indicates the organization's tendency towards bureaucracy and centralization, but it can vary widely between organizations and even within organizations. 
Given the characteristics of the variables, as well as the hypotheses to be tested, Spearman rank order correlation test was chosen because it can properly measure both the strength and direction of association between two ranked variables in order to enable identification of significant relations between the variables tested. Null-hypothesis rejections ( $\mathrm{p}$ value $\leq$ 0.05 ) indicate the presence of relations, while non-significant results ( $\mathrm{p}$ value $>0.05$ ) indicate the absence of statistically significant relations.

The second statistical test was used to analyze the significance of the relations between the specific roles performed by the individual companies within the $\mathrm{SC}$ and the usage patterns of individual performance indicators among SC roles.

The set of performance indicators used by different companies may be formed according to the characteristics and managerial needs of the companies, and the position of individual companies in the SC structure may affect their relevance.

Senior managers from all individual companies were asked to indicate which of the 49 performance indicators presented were used in search of usage patterns among SC roles. This was achieved by testing the two hypotheses below.

$\mathrm{H}_{0}$ : usage patterns for performance indicators are similar among SC roles.

$\mathrm{H}_{1}$ : usage patterns for performance indicators are different among SC roles.

Fisher's exact test is useful for examining the significance of the association between the two categorical variables. To carry out this test, the six possible two-by-two combinations of the four SC roles were each assessed for both hypotheses: 
- Combination I for input suppliers and farmers;

- Combination II for input suppliers and distributors;

- Combination III for input suppliers and retailers;

- Combination IV for farmers and distributors;

- Combination V for farmers and retailers;

- Combination VI for distributors and retailers.

Fisher's exact test enabled the identification of similarities in the usage patterns for each performance indicator. Null-hypothesis rejections ( $\mathrm{p}$ value $\leq 0.05$ ) indicate significant differences between usage patterns, while non-significant results ( $\mathrm{p}$ value $>0.05$ ) indicate similarity.

The third statistical test was used to analyze the significance of the relations between the specific roles performed by the individual companies within the SC and the intensity of the performance indicators usage patterns of the four perspectives of the BSC. The literature points out that the balance between the BSC perspectives is a central issue, however, the understanding of balance does not mean that the four perspectives should be considered equally important.

The Kruskal-Wallis test is suited to identifying whether the mean ranks are the same in all the groups. This enabled the identification of similarities and differences in the usage percentages relating to performance-indicator groups from the four perspectives of the BSC by testing the following hypotheses. 
$\mathrm{H}_{0}$ : the intensity of usage patterns is similar among the perspectives of BSC.

$\mathrm{H}_{1}$ : the intensity of usage patterns is different among the perspectives of BSC.

A null-hypothesis rejection ( $\mathrm{p}$ value $\leq 0.05$ ) from Kruskal-Wallis test indicates a significant difference in the intensity of an usage pattern among the four perspectives of the BSC, while a non-significant result ( $\mathrm{p}$ value $>0.05$ ) indicates a similarity.

\section{Results}

Initially, responses obtained from senior managers regarding the information asked regarding level of education and professional experience of senior managers, size, power and maturity were used to identify their respective relative distributions within three stage Likert scales. The results are presented in Table 2.

Table 2: information collected according to $\mathrm{SC}$ role (\%)

\section{Input}

Information suppliers Farmers Distributers Retailers

Level of education of senior managers

$\begin{array}{ccccc}\text { Undergraduate } & 70.9 & 7.7 & 38.3 & 63.3 \\ \text { Graduate } & 25.8 & 69.2 & 44.6 & 33.3 \\ \text { Post-graduate } & 3.3 & 23.1 & 17.1 & 3.4\end{array}$

Professional experience of senior managers

$\begin{array}{lllll}\text { Up to } 5 \text { years } & 35.4 & 23.1 & 31.9 & 53.3 \\ 6-15 \text { years } & 32.3 & 53.8 & 36.2 & 26.6 \\ & 32.3 & 23.1 & 31.9 & 20.1\end{array}$

Size of individual companies 


$\begin{array}{lcccc}\text { Small } & 58.1 & 30.7 & 57.4 & 53.4 \\ \text { Medium } & 12.8 & 15.4 & 14.9 & 23.3 \\ \text { Large } & 29.1 & 53.9 & 27.7 & 23.3\end{array}$

Power of individual companies

$\begin{array}{ccccc}\text { Little } & 12.9 & 46.2 & 44.7 & 26.7 \\ \text { Medium } & 9.6 & 23.1 & 29.8 & 46.6 \\ \text { Great } & 77.5 & 30.7 & 25.5 & 26.7\end{array}$

Maturity of individual companies

\begin{tabular}{|c|c|c|c|}
\hline Up to 10 years & 29.1 & 15.3 & 36.1 \\
\hline $11-20$ years & 22.5 & 38.5 & 38.3 \\
\hline More than 20 years & 48.4 & 46.2 & 25.6 \\
\hline
\end{tabular}

The results indicate that the aspects considered present different Likert scales percentages according to SC roles. Input suppliers are small, mature individual companies with great power managed by undergraduate senior managers. Farmers are large, mature individual companies with low power managed by graduate senior managers. Distributers are small relatively new individual companies with low power. Retailers are small, medium power relatively new individual companies with medium power managed by undergraduate senior managers.

Senior managers also provided information about the formalization degree of performance measurement procedures and the number of performance indicators used by individual companies. The results are presented in Table 3. 
Table 3: formalization degree of performance measurement procedures according to SC role $(\%)$

\section{Input}

Information

suppliers Farmers Distributers Retailers

Informal

41.9

23.2

21.3

36.7

Formal procedures

51.6

38.4

31.8

50.0

Standardized formal procedures

$6.5 \quad 38.4$

46.1

13.2

The results point out that the formalization degree of performance measurement procedures carried out by individual companies may change according to SC roles. A small percentage of input suppliers and retailers declared apply standardized formal procedures but they present the highest usage percentages regarding informal procedures whereas farmers and distributors have broadly implemented formal performance measurement procedures (standardized or not).

The responses obtained from the individual companies were also used to calculate the intensity of performance indicator usage relating to the performance indicators grouped under the BSC perspectives mentioned. The results relating to the usage of performance indicators from the financial perspective of the BSC are presented in Table 4.

Table 4: intensity of performance indicator usage from the financial perspective according to $\mathrm{SC}$ role $(\%)$

\section{Input}

Performance indicators

Profitability suppliers Farmers Distributers Retailers

$\begin{array}{llll}90.32 & 84.62 & 65.96 & 100.00\end{array}$




$\begin{array}{lcccc}\text { Liquidity } & 6.45 & 53.85 & 51.06 & 13.33 \\ \text { Revenues from products } & 32.26 & 61.54 & 48.94 & 20.00 \\ \text { Revenue per employee } & 3.23 & 23.08 & 17.02 & 0.00 \\ \text { Contribution margin } & 3.23 & 30.77 & 25.53 & 0.00 \\ \text { Level of indebtedness } & 3.23 & 23.08 & 36.17 & 40.00 \\ \text { Return on investment } & 16.13 & 15.38 & 19.15 & 20.00 \\ \text { Unit cost } & 67.4 & 61.54 & 38.30 & 3.33 \\ \text { Minimizing costs } & 70.97 & 84.62 & 59.57 & 100.00 \\ \text { Profit maximization } & 38.71 & 61.54 & 36.17 & 23.33 \\ \text { Inventory } & 3.23 & 61.54 & 12.77 & 3.33 \\ \text { Overall earnings } & 12.90 & 38.46 & 23.40 & 3.33 \\ \text { Operational costs } & 45.16 & 76.92 & 25.53 & 0,00\end{array}$

The results show that for all SC roles no performance indicator is applied more than the one relating to profitability, which is used by over $75 \%$ of the companies from three SC roles combined (input suppliers, farmers, and retailers) and by $65 \%$ of the distributors. Farmers and retailers present the same usage percentages for minimizing costs as they do for profitability; all retailers use both of these performance indicators. Unsurprisingly, the proportion of farmers using performance indicators for operational costs is above $75 \%$.

The detailed analysis for the intensity of the usage of performance indicators from the customer perspective of the BSC is presented in Table 5 .

Table 5: intensity of performance indicator usage from the customer perspective, according to supply chain role $(\%)$ 


\section{Input}

Performance indicators

suppliers Farmers Distributers Retailers

\begin{tabular}{lcccc}
\hline Customer satisfactions & 87.10 & 84.62 & 72.34 & 76.67 \\
Customer loyalty & 51.60 & 61.54 & 63.83 & 46.67 \\
New customers & 80.65 & 61.54 & 34.04 & 43.33 \\
Market share & 32.26 & 61.54 & 42.55 & 0.00 \\
Brand value & 19.35 & 53.85 & 14.89 & 0.00 \\
Profitability by customer & 6.45 & 46.15 & 25.53 & 10.00 \\
Revenue per customer & 3.23 & 53.85 & 38.30 & 10.00 \\
Business partner satisfaction & 35.48 & 61.54 & 19.15 & 26.67 \\
Delivery time & 90.32 & 0.00 & 21.28 & 23.33 \\
Responsiveness to clients & 3.23 & 23.08 & 12.77 & 3.33 \\
Growth in market share & 3.23 & 38.46 & 12.77 & 0.00 \\
Maximizing sales & 35.48 & 76.92 & 42.55 & 63.33
\end{tabular}

The results reveal that customer satisfaction is the most widely used performance indicator across the SC as a whole. Over $90 \%$ of input suppliers use the performance indicator for new customers, which is the most-used indicator by any SC role, and over $80 \%$ of this SC role use the performance indicator for delivery time. More than $75 \%$ of farmers use the indicator relating to maximizing sales.

The detailed analysis relating to performance indicators from the internal processes perspective of the BSC is presented in Table 6. 
Table 6: intensity of performance indicator usage from the internal processes perspective that presented null hypothesis rejections (\%)

\section{Input}

Performance indicators

New products

New processes

Productivity by business unit

Product turnover

After sales

Operational cycle

Suppliers

Waste

Flexibility

Responsiveness to customers

Delay in delivery

Responsiveness of suppliers

Storage time

Information/integration of materials suppliers Farmers Distributers Retailers

\begin{tabular}{|c|c|c|c|}
\hline 87.10 & 53.85 & 40.43 & 86.67 \\
\hline 35.48 & 76.92 & 29.79 & 33.33 \\
\hline 6.45 & 53.85 & 14.89 & 0.00 \\
\hline 3.23 & 46.15 & 36.17 & 3.33 \\
\hline 12.90 & 53.85 & 25.53 & 30.00 \\
\hline 51.61 & 53.85 & 14.89 & 0.00 \\
\hline 54.84 & 46.15 & 46.81 & 26.67 \\
\hline 3.23 & 61.54 & 42.55 & 13.33 \\
\hline 12.90 & 69.23 & 34.04 & 3.33 \\
\hline 3.23 & 0.00 & 8.51 & 10.00 \\
\hline 0.00 & 0.00 & 8.51 & 16.67 \\
\hline 35.48 & 61.54 & 19.15 & 26.67 \\
\hline 6.45 & 53.85 & 34.04 & 3.33 \\
\hline 0.00 & 38.46 & 8.1 & 0.00 \\
\hline
\end{tabular}

The results show that the performance indicator relating to new products was used by over $87 \%$ of the input suppliers and $86 \%$ of the retailers, and that $76 \%$ of farmers used the performance indicator for new processes.

The detailed analysis relating to performance indicators from the learning and growth perspective of the BSC is presented in Table 7. 
Table 7: intensity of performance indicator usage, according to supply chain role, from the learning and growth perspective that presented null-hypothesis rejections (\%)

\section{Input}

Performance indicators

suppliers Farmers Distributers Retailers

\begin{tabular}{lcccc}
\hline Investment in training & 9.68 & 69.23 & 40.43 & 40.00 \\
Investment in technology & 6.45 & 69.23 & 55.32 & 13.33 \\
Investment in information systems & 12.90 & 69.23 & 40.43 & 16.67 \\
Employee motivation & 51.61 & 38.46 & 48.94 & 13.33 \\
Employee capability & 67.74 & 46.15 & 36.17 & 23.33 \\
Managerial efficiency & 6.45 & 53.85 & 27.66 & 6.67 \\
Employee satisfaction & 38.71 & 53.85 & 51.06 & 6.67 \\
Innovative management & 3.23 & 53.85 & 17.02 & 3.33 \\
Number of complaints & 22.58 & 0.00 & 12.77 & 0.00 \\
Risk management & 0.00 & 38.46 & 14.89 & 0.00
\end{tabular}

None of the learning and growth performance indicators tested was used by more than $70 \%$ of any SC role.

The responses regarding performance indicator usage intensity were also used to identify the number of performance indicators used by individual companies under the BSC perspectives mentioned according to SC role. The results are presented in Table 8. 
Table 8: number of performance indicators from the perspectives of BSC according to SC role $(\%)$

\section{Input}

Perspectives

suppliers Farmers Distributers Retailers

Financial

$\begin{array}{ccccc}\text { Up to } 3 \text { metrics } & 35.5 & 7.6 & 44.7 & 66.7 \\ 4-6 \text { metrics } & 61.3 & 46.2 & 29.8 & 26.7 \\ 7 \text { or more } & 3.2 & 46.2 & 25.5 & 6.6\end{array}$

Customer

$\begin{array}{ccccc}\text { Up to } 3 \text { metrics } & 32.2 & 7.6 & 34.1 & 66.7 \\ 4-6 \text { metrics } & 61.3 & 69.2 & 59.6 & 33.3 \\ 7 \text { or more } & 6.5 & 23.2 & 6.3 & 0.0\end{array}$

Internal processes

$\begin{array}{ccccc}\text { Up to } 3 \text { metrics } & 64.5 & 15.4 & 53.2 & 73.3 \\ 4-6 \text { metrics } & 35.5 & 46.1 & 40.4 & 23.3 \\ 7 \text { or more } & 0.0 & 38.5 & 6.4 & 3.4\end{array}$

Learning and growth

$\begin{array}{ccccc}\text { Up to } 10 \text { years } & 87.1 & 23.1 & 51.1 & 83.4 \\ 11-20 \text { years } & 12.9 & 46.1 & 42.6 & 16.6 \\ \text { More than } 20 \text { years } & 0.0 & 30.8 & 6.3 & 0.0\end{array}$

The results indicate that differences regarding the number of performance indicators from the perspectives of BSC according to SC roles. Farmers from the sample have been using at least four performance indicators, whereas retailers and distributors have been using fewer performance indicators (up to three) in all BSC perspective. Input suppliers have 
been using more financial and customer metrics than internal processes nor learning and growth metrics.

Spearman rank order correlation test enabled the identification of significant correlations between the formalization degree of performance measurement procedures, the number of performance indicators used according to BSC perspectives and the contingency factors from the individual companies. The results are presented in Table 9.

Table 9: Spearman correlation test results regarding the formalization degree of performance measurement procedures, the number of performance indicators used in each perspective of the BSC and the additional information collected according to SC roles

Learning

Internal and

Formalization Financial Customer processes growth

SC roles degree metrics metrics metrics metrics

Input suppliers

Formalization degree

$-0.02-0.39 *$

$-0.14$

$-0.15$

Managers' level of education

$0.39 *$

0.28

$-0.06$

0.10

$-0.04$

Managers' professional

$\begin{array}{cccccc}\text { experience } & -0.40^{*} & 0.17 & 0.53 * & 0.19 & 0.13 \\ \text { Companies size } & 0.48^{*} & 0.08 & -0.14 & -0.16 & -0.31 \\ \text { Companies power } & -0.38^{*} & 0.11 & 0.28 & 0.08 & -0.04 \\ \text { Companies maturity } & 0.00 & 0.26 & 0.10 & -0.01 & -0.29\end{array}$

Farmers

Formalization degree

$0.30 \quad-0.05$

$-0.18$

0.14 
$\begin{array}{llllll}\text { Managers' level of education } & 0.33 & 0.56^{*} & 0.10 & 0.24 & 0.13\end{array}$

Managers' professional

$\begin{array}{cccccc}\text { experience } & -0.41 & -0.52 & -0.63^{*} & -0.31 & -0.16 \\ \text { Companies size } & 0.25 & -0.25 & -0.04 & 0.11 & -0.47 \\ \text { Companies power } & -0.00 & -0.22 & -0.62^{*} & -0.69^{*} & -0.47 \\ \text { Companies maturity } & 0.53 & -0.27 & 0.29 & -0.00 & 0.09\end{array}$

Distributors

Formalization degree

- $\quad 0.44^{*}$

0.19

0.23

$0.49 *$

Managers' level of education

0.18

0.20

$0.29 *$

0.16

0.28

Managers' professional

$\begin{array}{cccccc}\text { experience } & -0.28^{*} & 0.01 & 0.09 & -0.14 & -0.19 \\ \text { Companies size } & 0.25 & 0.43^{*} & 0.14 & 0.25 & 0.09 \\ \text { Companies power } & 0.09 & -0.27 & 0.03 & -0.16 & -0.12 \\ \text { Companies maturity } & 0.00 & 0.12 & 0.14 & 0.05 & -0.13\end{array}$

Retailers

$\begin{array}{cccccc}\text { Formalization degree } & - & 0.20 & 0.31 & 0.26 & 0.19 \\ \text { Managers' level of education } & 0.16 & 0.39^{*} & 0.36^{*} & 0.36^{*} & 0.61^{*} \\ \text { Managers' professional } & & & & \\ \quad \text { experience } & -0.17 & 0.28 & 0.25 & 0.30 & 0.09 \\ \quad \text { Companies size } & 0.30 & 0.12 & 0.34 & 0.34 & -0.05 \\ \text { Companies power } & -0.26 & -0.14 & 0.00 & -0.22 & 0.12 \\ \text { Companies maturity } & -0.15 & 0.06 & 0.00 & 0.04 & -0.14\end{array}$

The results indicate the presence of several statistically significant correlations between the variables tested regarding all SC roles. Input suppliers' results point out that the 
formalization degree of performance measurement procedures should be considered as positively correlated to senior manager's level of education and companies' size, but negatively correlated to senior manager's professional experience, and companies' power. The formalization degree should be considered as negatively correlated to senior manager's professional experience among distributors. The formalization degree of performance measurement procedures presented no significant correlation with contingency factors among neither farmers nor retailers. Each SC role presented specific results regarding statistically significant correlations between the contingency factors tested and the number of metrics from the perspectives of the BSC.

Fisher's exact test was used to analyze the statistical significance of the relations between the roles performed by the individual companies within the SC and their usage patterns identified for all 49 performance indicators. Using a two-by-two contingency table, each performance indicator was tested for all six combinations of the four SC roles. The results relating to performance indicators from the financial perspective of the BSC are presented in Table 10.

The results show that the return on investment performance indicator was the only one that did not present null-hypothesis rejection among the two-by-two combinations. These results indicate that the usage patterns relating to this performance indicator are similar in all SC roles, although the usage percentages reveal that it has not been widely used among the individual companies polled. 
Table 10: Fisher's exact test results regarding performance indicators for the financial

perspective, according to combination

\section{Financial Combination Combination Combination Combination Combination Combination}

\begin{tabular}{lcccccr} 
indicators & I & II & III & IV & V & VI \\
\hline Profitability & 0.46 & 0.01 & 0.11 & 0.17 & 0.08 & 0.00 \\
\hline Liquidity & 0.00 & 0.00 & 0.17 & 0.55 & 0.00 & 0.00
\end{tabular}

\section{Revenues}

from

\begin{tabular}{|c|c|c|c|c|c|c|}
\hline products & 0.07 & 0.10 & 0.19 & 0.31 & 0.01 & 0.00 \\
\hline \multicolumn{7}{|l|}{ Revenue per } \\
\hline employee & 0.07 & 0.06 & 0.50 & 0.44 & 0.02 & 0.01 \\
\hline \multicolumn{7}{|l|}{ Contribution } \\
\hline margin & 0.02 & 0.00 & 1 & 0.47 & 0.00 & 0.00 \\
\hline \multicolumn{7}{|l|}{ Level of } \\
\hline indebtedness & 0.07 & 0.00 & 0.00 & 0.29 & 0.23 & 0.45 \\
\hline
\end{tabular}




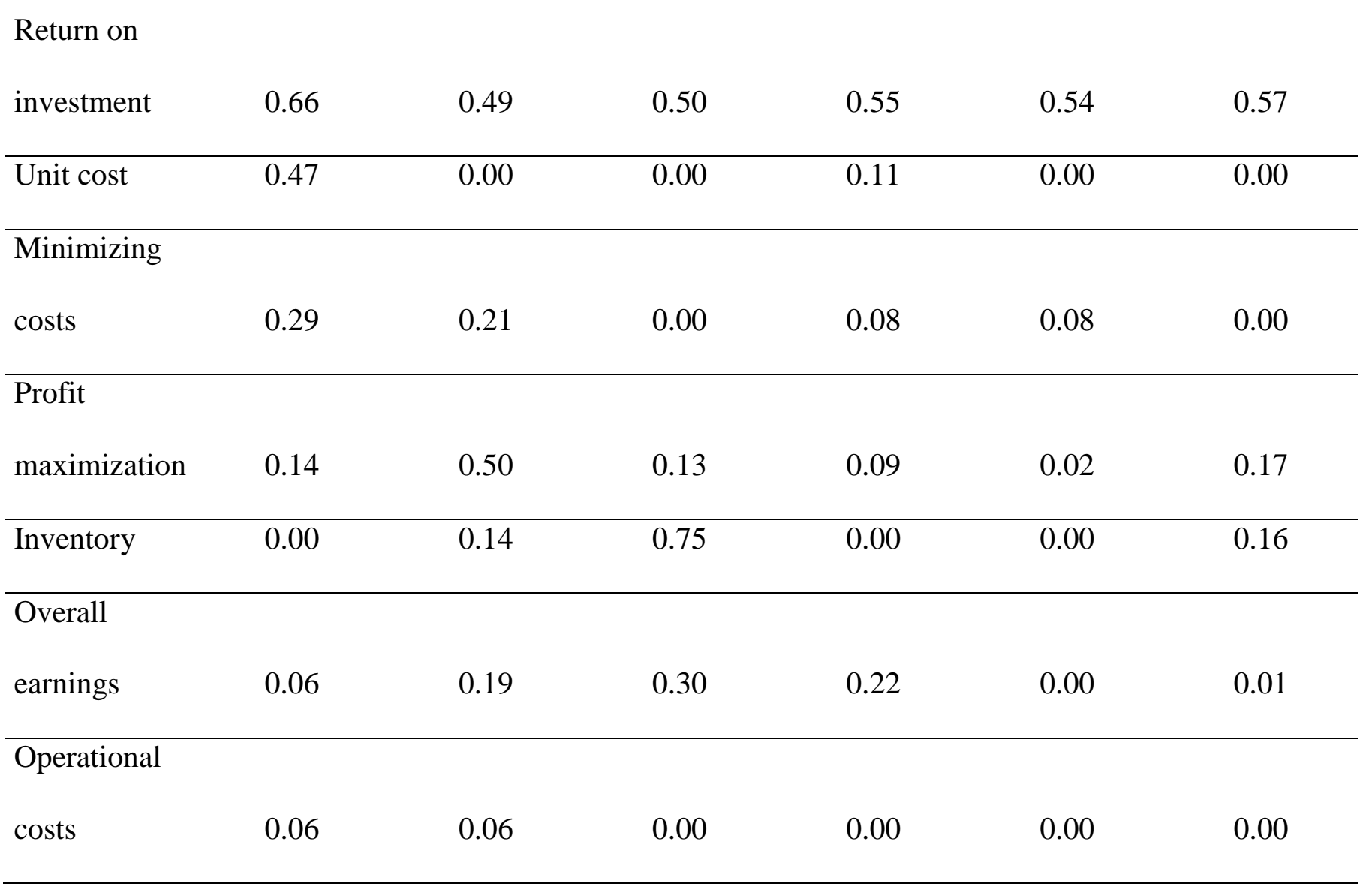


The results from the other 12 financial performance indicators show evidence (nullhypothesis rejections) indicating the presence of significant differences in usage patterns among SC roles. Profit maximization presented one rejection. It should also be pointed out that traditional financial indicators (such as liquidity, contribution margin, unit costs, and operational costs) did not obtain satisfactory results.

The same test was performed with the performance indicators from the customer perspective. The results are presented in Table 11.

The results show that three performance indicators from the customer perspective (customer satisfaction, customer loyalty, and responsiveness to clients) did not present any null-hypothesis rejection among the two-by-two combinations. This indicates that the usage patterns relating to these performance indicators are similar in all SC roles. The usage percentages reveal that customer satisfaction has been widely used among all four $\mathrm{SC}$ roles, but this is not the case for responsiveness to clients. The usage percentages from the performance indicator for customer loyalty do not provide any clear solution relating to this anomaly.

The results from the remaining nine performance indicators from this perspective present null-hypothesis rejections, which indicates that there are significant differences in the usage patterns among SC roles. Several traditional customer performance indicators (such as delivery time, growth in market share, revenue per customer, and brand value) presented null-hypothesis rejections. The results for performance indicators related to the internal processes perspective of the BSC are presented in Table 12. 
Table 11: Fisher's exact test results regarding performance indicators for the customer perspective, according to combination.

\section{Customer Combination Combination Combination Combination Combination Combination}

\begin{tabular}{|c|c|c|c|c|c|c|}
\hline indicators & I & II & III & IV & $\mathbf{V}$ & VI \\
\hline \multicolumn{7}{|l|}{ Customer } \\
\hline satisfaction & 0.58 & 0.10 & 0.23 & 0.30 & 0.44 & 0.44 \\
\hline \multicolumn{7}{|l|}{ Customer } \\
\hline loyalty & 0.39 & 0.20 & 0.50 & 0.56 & 0.28 & 0.10 \\
\hline New customers & 0.16 & 0.00 & 0.00 & 0.14 & 0.22 & 0.49 \\
\hline Market share & 0.07 & 0.25 & 0.00 & 0.18 & 0.00 & 0.00 \\
\hline Brand value & 0.02 & 0.41 & 0.01 & 0.00 & 0.00 & 0.02 \\
\hline \multicolumn{7}{|l|}{ Profitability } \\
\hline per customer & 0.00 & 0.02 & 0.30 & 0.13 & 0.01 & 0.08 \\
\hline Revenue per & 0.00 & 0.00 & 0.30 & 0.24 & 0.00 & 0.00 \\
\hline
\end{tabular}


customer

Business

partner

satisfaction

0.58

0.07

0.00

0.25

0.01

0.01

\begin{tabular}{lcccccc}
\hline Delivery time & 0.00 & 0.00 & 0.00 & 0.06 & 0.06 & 0.52 \\
\hline Responsiveness & & & & & \\
to clients & 0.07 & 0.14 & 0.50 & 0.29 & 0.07 & 0.16 \\
\hline Growth in & & & & & 0.04 \\
market share & 0.00 & 0.14 & 1 & 0.04 & 0.00 & 0.06 \\
Maximizing & & & & & & 0.30 \\
sales & 0.01 & 0.35 & 0.03 & 0.02 & 0.30
\end{tabular}


Table 12: Fisher's exact test results regarding the performance indicators for the internal processes perspective, according to combination.

Internal Combination Combination Combination Combination Combination Combination

$\begin{array}{llllllll}\text { processes } & \text { I } & \text { II } & \text { III } & \text { IV } & \text { V } & \text { VI } \\ \text { indicators } & & & & & & \end{array}$

\begin{tabular}{lcccccc}
\hline New products & 0.02 & 0.00 & 0.64 & 0.29 & 0.02 & 0.00 \\
\hline New processes & 0.01 & 0.38 & 0.50 & 0.00 & 0.01 & 0.46 \\
\hline Productivity & & & & & \\
per business & & & & & \\
unit & 0.00 & 0.22 & 0.24 & 0.00 & 0.00 & 0.02 \\
\hline Product & & & & & \\
turnover & 0.00 & 0.00 & 0.75 & 0.36 & 0.00 & 0.00 \\
\hline After sales & 0.00 & 0.14 & 0.06 & 0.06 & 0.12 & 0.43 \\
\hline Operational & 0.57 & 0.00 & 0.00 & 0.00 & 0.00 & 0.02
\end{tabular}


cycle

\begin{tabular}{|c|c|c|c|c|c|c|}
\hline Suppliers & 0.42 & 0.32 & 0.01 & 0.60 & 0.18 & 0.06 \\
\hline Waste & 0.00 & 0.00 & 0.17 & 0.18 & 0.00 & 0.00 \\
\hline Flexibility & 0.00 & 0.03 & 0.17 & 0.02 & 0.00 & 0.00 \\
\hline \multicolumn{7}{|c|}{ Responsiveness } \\
\hline to customers & 0.70 & 0.33 & 0.30 & 0.36 & 0.32 & 0.56 \\
\hline \multicolumn{7}{|l|}{ Delay in } \\
\hline delivery & 1 & 0.12 & 0.02 & 0.36 & 0.14 & 0.23 \\
\hline \multicolumn{7}{|c|}{ Responsiveness } \\
\hline of suppliers & 0.10 & 0.08 & 0.38 & 0.00 & 0.03 & 0.30 \\
\hline Storage time & 0.00 & 0.00 & 0.50 & 0.16 & 0.00 & 0.00 \\
\hline \multicolumn{7}{|l|}{ Information } \\
\hline \multicolumn{7}{|c|}{ and integration } \\
\hline of materials & 0.00 & 0.12 & 1 & 0.01 & 0.00 & 0.13 \\
\hline
\end{tabular}


Only the performance indicator relating to responsiveness to customers did not present rejections of the null hypothesis. The usage patterns relating to the other performance indicators can be considered to be similar in all SC roles. However, the usage percentages reveal that it has not been widely used among the individual companies polled.

Conversely, traditional internal-processes performance indicators (such as after sales, suppliers, storage time, delay in delivery, product turnover operational cycle, and flexibility) did obtain null-hypothesis rejections.

Finally, this test was performed with the performance indicators for the learning and growth perspective. The results are presented in Table 13.

The performance indicators from this perspective did not provide satisfactory results. All results from the learning and growth performance indicators show evidence of nullhypothesis rejections, indicating the presence of significant differences in the usage patterns among SC roles.

The results from the Fisher's exact tests were also examined for an overall perception of two structural aspects: the two-by-two combinations of the four SC roles and the four perspectives from the BSC. The results for the two-by-two combinations are presented in Table 14. 
Table 13: Fisher's exact test results regarding the performance indicators for the learning

and growth perspective, according to combination.

\section{Learning and Combination Combination Combination Combination Combination Combination}

$\begin{array}{lllllll}\text { growth } & \text { I } & \text { II } & \text { III } & \text { IV } & \text { V } & \text { VI }\end{array}$

indicators

Investment in

\begin{tabular}{lcccccc} 
training & 0.00 & 0.00 & 0.00 & 0.06 & 0.07 & 0.58 \\
\hline Investment in & & & & & & \\
technology & 0.00 & 0.00 & 0.17 & 0.28 & 0.00 & 0.00 \\
\hline
\end{tabular}

Investment in

information

\begin{tabular}{lcccccc} 
systems & 0.00 & 0.00 & 0.50 & 0.06 & 0.00 & 0.02 \\
\hline Employee & & & & & & \\
motivation & 0.32 & 0.50 & 0.00 & 0.36 & 0.07 & 0.00 \\
\hline Employee & 0.15 & 0.00 & 0.00 & 0.36 & 0.12 & 0.17
\end{tabular}


capability

\begin{tabular}{|c|c|c|c|c|c|c|}
\hline Managerial & & & & & & \\
\hline efficiency & 0.00 & 0.01 & 0.50 & 0.07 & 0.00 & 0.02 \\
\hline Employee & & & & & & \\
\hline satisfaction & 0.27 & 0.20 & 0.00 & 0.55 & 0.00 & 0.00 \\
\hline Innovative & & & & & & \\
\hline management & 0.00 & 0.06 & 0.50 & 0.01 & 0.00 & 0.06 \\
\hline Number of & & & & & & \\
\hline complaints & 1 & 0.12 & 0.02 & 0.36 & 0.14 & 0.23 \\
\hline Risk & & & & & & \\
\hline management & 0.00 & 0.02 & 1 & 0.07 & 0.00 & 0.02 \\
\hline
\end{tabular}

Table 14: outcome of the tests for the two-by-two combinations of SC roles

\section{Results that do Results that do Number of tests}

Two-by-two combinations

not reject $\mathrm{H}_{0} \quad$ reject $\mathrm{H}_{0} \quad$ performed

Combination I

25

24

49 


\begin{tabular}{lccc} 
Combination II & 28 & 21 & 49 \\
\hline Combination III & 31 & 18 & 49 \\
\hline Combination IV & 37 & 12 & 49 \\
\hline Combination V & 18 & 31 & 49 \\
\hline Combination VI & 22 & 27 & 49 \\
\hline Overall & 161 & 133 & 294 \\
\hline
\end{tabular}

Table 14 
Several relevant points can be drawn from these results. Firstly, the overall percentage of null-hypothesis rejections (approximately $45 \%$ of all tests performed) indicates that usage patterns for performance indicators change according to the role of an agribusiness company in its SC, suggesting that some management concerns about SCPM reflect rolerelated issues.

Secondly, the differences found between the combinations tests confirm the importance of role specificities. For each of the first four combinations the number of null-hypothesis rejections was smaller than the amount of results that did not indicate rejection; for combinations V and VI the amount of rejections of the null hypothesis was higher than the non-rejections.

The two-by-two combination that obtained the highest degree of similarity between the roles tested compared farmers and distributors. For this combination the null hypothesis was not rejected in approximately two-thirds of the performance indicators tested, which indicates that the SCP management concerns of both roles are very similar to each other. In contrast, the two-by-two combination of farmers and retailers obtained the highest degree of difference, because the null hypothesis was rejected in approximately $65 \%$ of the performance indicators tested, which suggests the presence of significant differences among their managerial concerns regarding SCP.

As mentioned above, the results from the statistical tests were also examined with regard to the BSC. The results are presented in Table 15. 
Table 15: outcome of the tests for the Balanced Scorecard perspectives

\begin{tabular}{lcccc} 
& $\begin{array}{l}\text { Number of } \\
\text { performance }\end{array}$ & Number of & Results that & Results that \\
Perspectives & indicators & performed & reject Ho & do reject Ho \\
\hline Financial perspective & 13 & 78 & 46 & 32 \\
\hline Customer perspective & 12 & 72 & 42 & 30 \\
\hline Internal processes perspective & 14 & 84 & 43 & 41 \\
\hline Learning and growth & & & & \\
\hline perspective & 10 & 60 & 30 & 30 \\
\hline Overall & 49 & 294 & 161 & 133 \\
\hline
\end{tabular}

It can be seen that the intensity of null-hypothesis rejections varied among the perspectives tested, which confirms the presence of significant differences. The null hypothesis was not rejected in almost $60 \%$ of the tests concerning the performance indicators for the financial (59\%) and customer (58\%) perspectives. In contrast, half of the results of the tests for the learning and growth performance indicators returned null-hypothesis rejections. The table shows that each perspective from the BSC presented different managerial concerns about SCP from individual agribusiness companies, according to the four specified roles within the SC. In addition, two-by-two combinations and the perspectives of the BSC were also considered jointly. The results are presented in Table 16.

Table 16: percentage of null hypothesis rejections from the Balanced Scorecard perspectives for the two-by-two combinations 


\section{Combination Combination Combination Combination Combination Combination}

$\begin{array}{lllll}\text { I II } & \text { III } & \text { IV } & \text { V } & \text { VI }\end{array}$

\begin{tabular}{|c|c|c|c|c|c|c|}
\hline \multicolumn{7}{|l|}{ Financial } \\
\hline perspective & 23.08 & 38.46 & 30.77 & 15.38 & 69.23 & 69.23 \\
\hline \multicolumn{7}{|l|}{ Customer } \\
\hline perspective & 50.00 & 33.33 & 50.00 & 25.00 & 50.00 & 41.67 \\
\hline \multicolumn{7}{|l|}{ Internal } \\
\hline \multicolumn{7}{|l|}{ processes } \\
\hline perspective & 64.29 & 42.86 & 21.43 & 42.86 & 71.43 & 50.00 \\
\hline \multicolumn{7}{|l|}{ Learning } \\
\hline \multicolumn{7}{|l|}{ and growth } \\
\hline perspective & 60.00 & 60.00 & 50.00 & 10.00 & 60.00 & 60.00 \\
\hline
\end{tabular}

It can be seen that the percentage of null-hypothesis rejections varied significantly for the perspectives and the combinations. These findings provide evidence of significant differences among the perspectives as well as the two-by-two combinations.

The financial perspective and the customer perspective, although there were differences between them, presented the lowest percentages of rejections for the combined combinations, while the learning and growth perspective obtained the highest overall percentages of rejections. The results also varied significantly when considering the point of view of the two-by-two combinations, with Combination IV returning the lowest percentages of rejections and Combination V obtaining the highest percentages. 
These findings from the tested structural characteristics provide empirical evidence that managerial discrepancies in SCPM among individual agribusiness companies is somehow related to the role the individual business undertake in its SC.

Secondly, the Kruskal-Wallis test was performed to analyze the statistical significance of the relations between specific roles performed by the individual companies within the SC and the performance indicators usage patterns relating to the four perspectives of the BSC considering their respective usage percentages. The results relating to performance indicators from the financial perspective are presented in Figure 1.

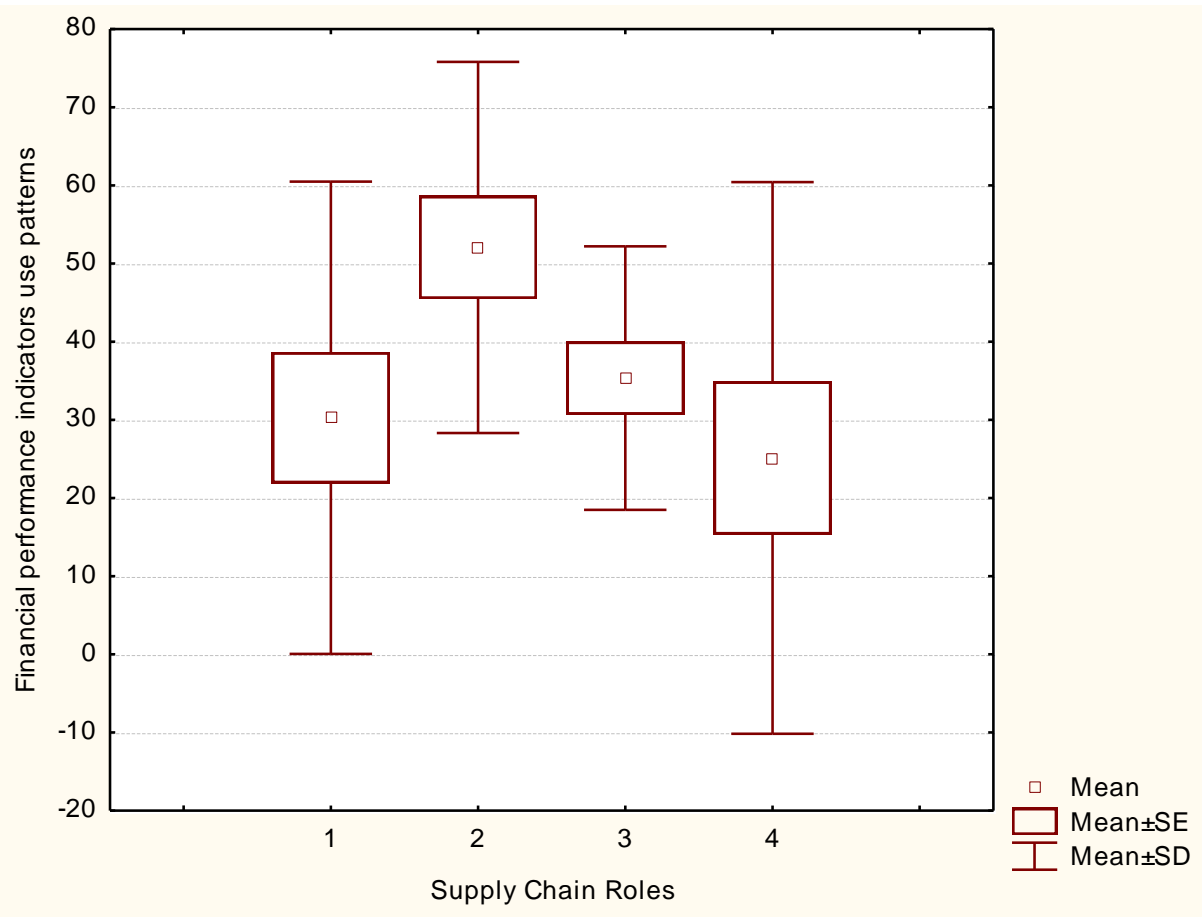

Figure 1: results of the tests from the usage patterns of the performance indicators for the financial perspective, according to supply chain role 
Notes: (1) input suppliers; (2) farmers; (3) distributors; (4) retailers; (SE) standard error; (SD) standard deviation, $\mathrm{p}=0.02$.

The statistical significance obtained indicates that the four SC roles investigated do not share similar levels of managerial concerns about SCP relating to financial issues. Furthermore, the results suggest that the roles should be considered very differently from each other.

Figure 1 illustrates how the intensity of the usage patterns for the performance indicators changes across the SC, increasing from suppliers to farmers, but decreasing from farmers to retailers. Farmers reveal the highest levels of usage patterns relating to financial performance indicators, while retailers show the lowest.

The results from performance indicators for the customer perspective are presented in Figure 2. 


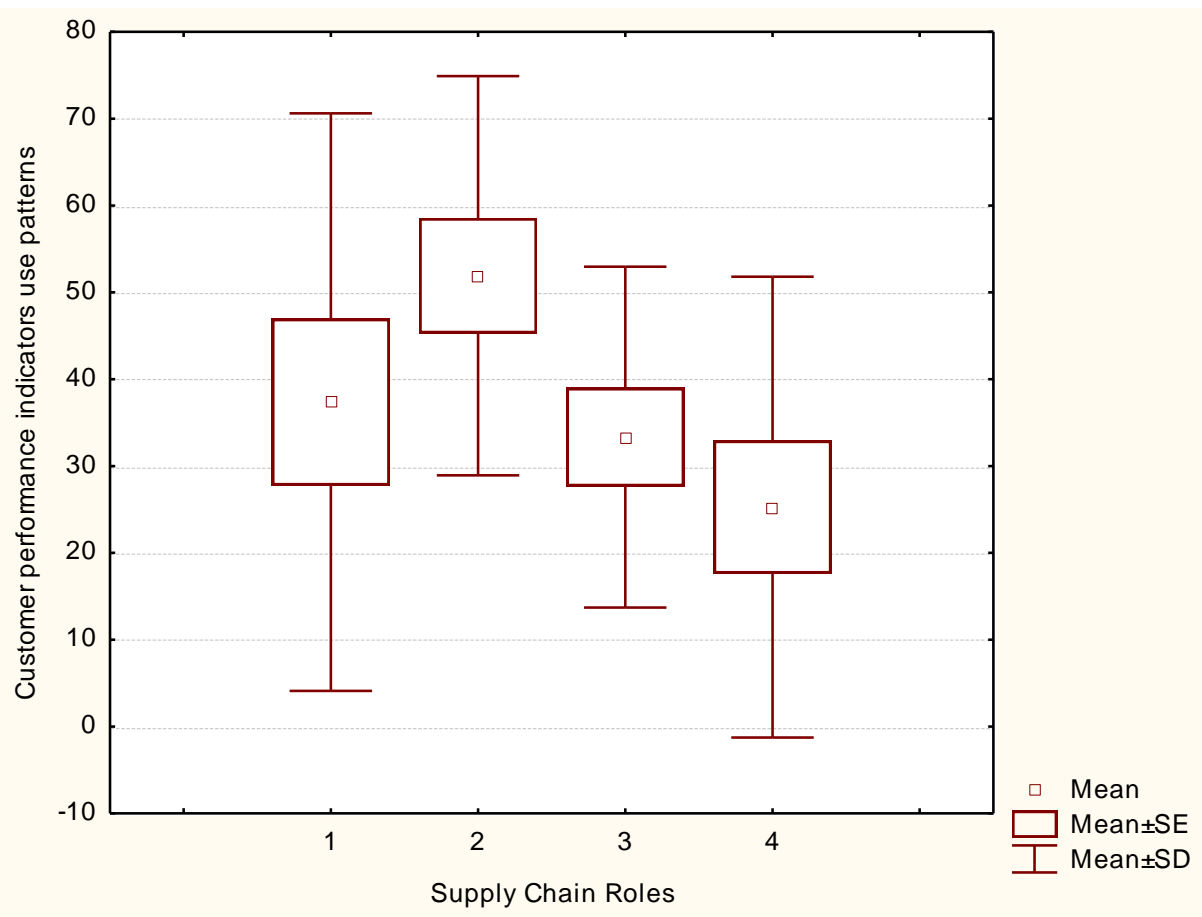

Figure 2: results of the tests from the usage patterns of the performance indicators for the customer perspective, according to supply chain role

Notes: (1) input suppliers; (2) farmers; (3) distributors; (4) retailers; (SE) standard error; (SD) standard deviation, $\mathrm{p}=0.10$.

These results show that the differences in the intensity of the usage patterns relating to customer performance indicators were not statistically significant, indicating that SC roles share a similar level of managerial concern about performance relating to customer issues.

The same test was performed with the performance indicators from the internal processes perspective. The results are presented in Figure 3. 


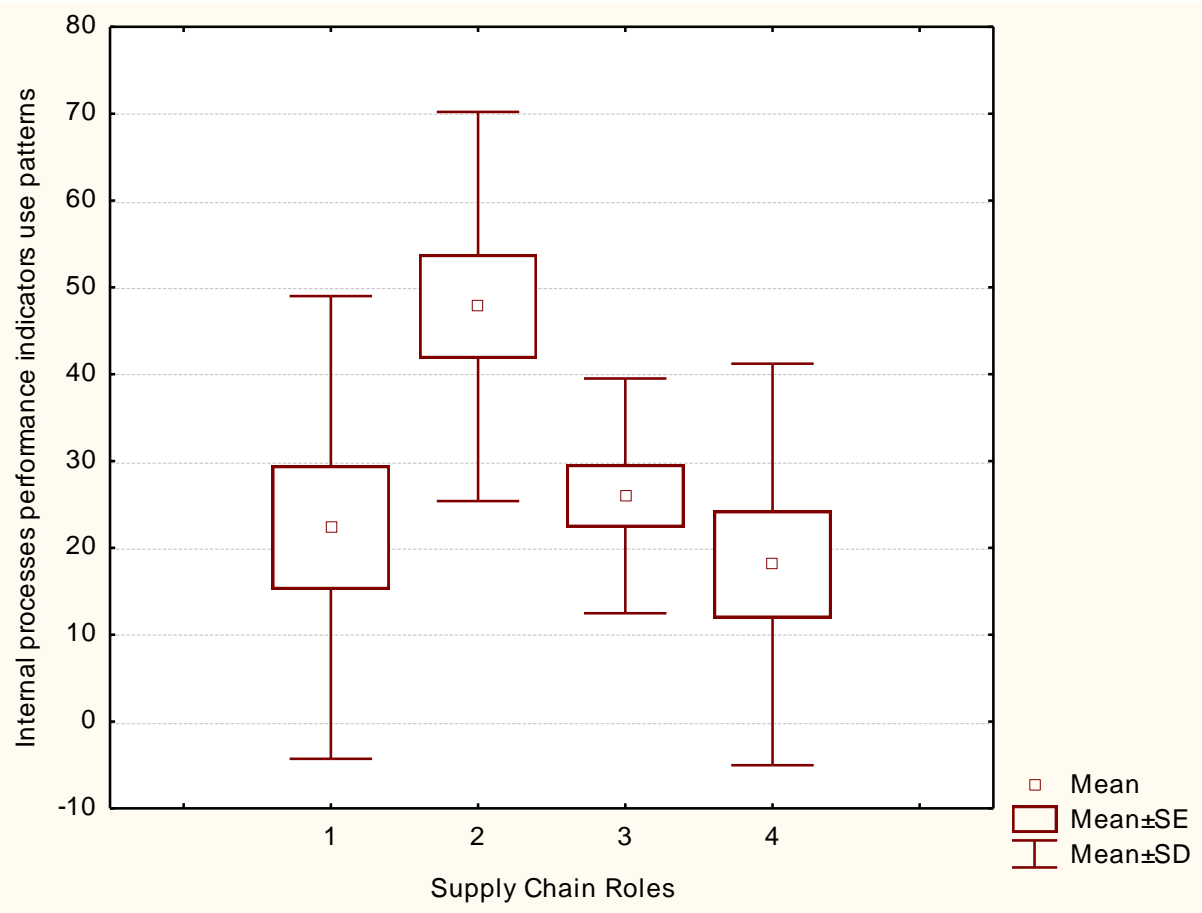

Figure 3: results of the tests from the usage patterns of the performance indicators for the internal processes perspective, according to supply chain role

Notes: (1) input suppliers; (2) farmers; (3) distributors; (4) retailers; (SE) standard error; (SD) standard deviation, $\mathrm{p}=0.00$.

The results were statistically significant $(\mathrm{p}=0.00)$, indicating that the four SC roles investigated do not share similar levels of managerial concerns about SCP relating to internal processes issues. The differences in the intensity of the usage patterns of the performance indicators across the $\mathrm{SC}$ as presented in Figure 3 are similar to those presented in Figure 1.

Finally, the same procedure was performed with the performance indicators from the learning and growth perspective. The results are presented in Figure 4. 


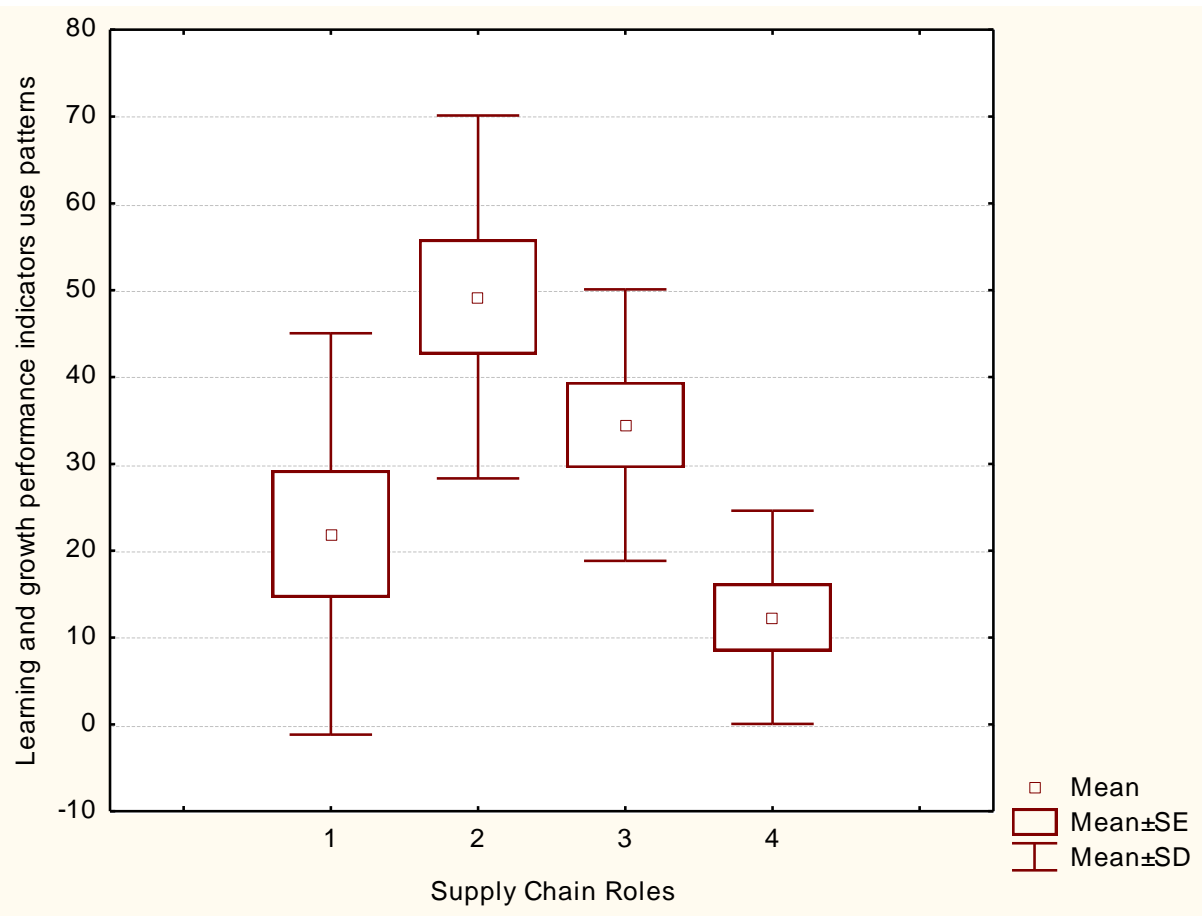

Figure 4: results of the tests from the usage patterns of the performance indicators for the learning and growth perspective, according to supply chain role

Notes: (1) input suppliers; (2) farmers; (3) distributors; (4) retailers; (SE) standard error; (SD) standard deviation, $\mathrm{p}=0.00$.

The results were statistically significant $(p=0.00)$. However, this time the box-plot positioning illustrates clearly the intensity levels of the usage patterns. Farmers present the highest level, followed by distributors and then input suppliers, with retailers showing the lowest level.

These findings provide empirical evidence that supports the presence of differences in the usage patterns of performance indicators among SC roles relating to individual performance indicators and the perspectives of the BSC. For management accountants, this is a timely reminder that performance measures need to be understood in the context of 
the specific industry and specific roles that are found within the supply networks they are monitoring and evaluating.

\section{Discussion}

Vachon et al (2009) and others show that the greater the degree of integration and information sharing in supply chains, the greater the benefit to all partners in the chain. These benefits are financial and build resilience for suppliers. ASC are known to be fragmented and highly competitive, characterized by a lack of information sharing (Jack et al, 2013; Cox and Chicksand, 2007; Hingley 2005). The purpose of this paper was to explore the nature of information shared in terms of performance metrics, in order to understand further where ASC might be strengthened in order to return greater benefits to suppliers.

It is accepted in the literature (Holmberg, 2000; Fauske et al., 2007; Bigliardi et al., 2010) that a small group of individual performance indicators is more likely to be suitable for SC performance measurement. The results presented conform to this expectation. Only five performance indicators did not show any significant difference in the usage patterns among $\mathrm{SC}$ roles. Furthermore, client satisfaction was the single performance indicator that did not present statistically significant differences regarding its usage patterns among input suppliers, farmers, distributors and retailers. Chia et al. (2009) present similar results.

The number of SCP indicators with similar usage patterns among SC roles could have been higher had the samples comprised individual companies from similar SCs. 
The process identifying of a common set of standard performance indicators that fit each individual company in an SC is difficult because corporate characteristics such as organizational culture, managerial policies and operational routines influence the importance of measures (Holmberg, 2000; Park et al., 2005).

Shared metrics implementation has not been easily accomplished (Kleijnen et al., 2003). Once the common set of a certain number of standard performance indicators is accepted as the best approach to measure SCP and those indicators are identified, there is no assurance that this set of common indicators will be able to cover all relevant aspects that should be evaluated across the SC.

It has been noted that users of different performance indicators could place greater or lesser importance on specific metrics, according to the operational contribution of the indicator being used (Van Hoek, 1998; Kleijnen et al., 2003), indicating a hierarchy for SCP indicators, but these are not discussed at any length.

It is also interesting that the results showing the use of customer satisfaction as the only indicator present across multiple SCs also support the qualitative findings of Jack et al. (2012) in a UK/Spanish context, who noted that intermediary companies reported that the only meaningful negotiations with SC partners were based on customer satisfaction indicators. This is felt to be to the detriment of discussions about financial returns and fair pricing. Any discussion of the indicators that could be included in an SCPM system or BSC would need to include some difficult conversations about performance indicators in other areas: a balanced scorecard may help to promote these necessary yet difficult conversations. However, a limiting factor in our study is that customer satisfaction was not 
explored in more detail, and therefore, we are unable to comment on the nuances of how customer satisfaction was measured by those in different SC roles. As this was an exploratory study, further work is needed to collect data to test for the detailed variations of what constitutes the understanding of customer satisfaction in different entities.

The results also indicate significant structural differences relating to the intensity of the usage patterns for performance indicators among SC roles. Farmers, distributors, input suppliers, and retailers presented differences in usage patterns in three perspectives of the BSC. The customer perspective was the one perspective of the BSC that did not present statistically significant differences regarding the intensity of its usage patterns among input suppliers, farmers, distributors, and retailers. This suggests that specific roles may also address different levels of managerial attention relating to the performance measurement of specific issues.

The current situation in fresh fruit supply chains allows for all year supply of fruit in supermarkets and catering. Meeting consumer and customer demands is the dominant rhetoric but it has 'win-lose' implications for suppliers (Cox and Chicksand, 2007). The question, which we are unable to address directly from this dataset, is whether performance metrics relating to other aspects of SC such as finance, could be brought into negotiations between supply chain partners in order to create the benefits that come from greater integration and information sharing (Vachon et al, 2009; Schoetzler, 2012; Afuah, 2013). In an industry with narrow margins, suppliers tend to protect information in order to eke out sufficient profit and cash flow to survive (Jack et al, 2013). Understanding these issues, there are lessons for accountants involved in supply chain performance measurement across industries, namely that although a balanced approach might be desired 
it is likely that negotiations between supply chain partners will be restricted to certain customer related measures and that this might be to the exclusion of discussions about financial measures that impact on profitability.

\section{Conclusions}

The objective of this study was to look for similarities and differences in the patterns of use of performance indicators among Brazilian agribusiness companies, taking into consideration each company's role in its SC. To accomplish this objective, 121 individual agribusiness companies were surveyed. These are non-integrated supply chain businesses, which are less studied in the context of SCPM.

The findings contribute to the sparse literature on management control in non-integrated SC by providing evidence of which specific performance measures are likely to be used in negotiations by SC partners in ASC. This also has implications for the study of SCPM design, in that the context of ASC and the pressures upstream in SC of low prices, narrow margins and all year round supply, the non-sharing of common indicators leads to negotiations that may be sub-optimal for suppliers.

In terms of the development of SCPM practices, it is clear from the findings that individual companies and the managers within them use performance metrics that are relevant for their role and position in the supply chain - there are usage specificities. In other words, there are established patterns of performance measurement which from the literature must be seen in the context of a fragmented and fast-moving industry. However, the emergence from the data that there is just one common metric implies that negotiations between ASC partners are limited. Suggestions in the literature that BSC or other models of SCPM 
might be desirable are questioned in this context. This study highlights the practical difficulties in establishing the limited number of performance metrics which the literature suggests leads to optimal SC performance.

Therefore, SCPM design should view the SC as a single entity while considering the singular requirements of individual companies. However, the feasibility of an SCP system based on both common and specific performance indicators remains unclear. Further studies may generate more detailed information about the nature of the dynamic relationships between these two aspects and thereby contribute to the improvement of the existing knowledge about this field. Both accounting researchers and practitioners need to develop understanding of how performance measurement models for non-integrated SC might work, and how these need to take into consideration the specific contexts of industries and roles within different businesses engaged in supply chain partnerships. Our findings suggest that existing models such as balanced scorecards cannot be easily translated in these contexts and that further work is needed to develop measures and models that allow more scope for negotiation between supply chain partners in situations where margins are at risk.

\section{References}

Afuah, A. (2013). Are network effects really all about size? The role of structure and conduct. Strategic Management Journal, Vol. 34, No. 3, pp.257-273.

Akyuz, G.A. and Erkan, T.E. (2010). Supply chain performance measurement: a literature review. International Journal of Production Research, Vol. 48, No.17, pp.5137-5155. 
Beamon, B. (1998). Supply chain and analysis models and methods. International Journal of Production Economics, Vol. 55 No. 3, pp.281-294.

Beamon, B. (1999). Measuring supply chain performance. International Journal of Operations and Production Management, Vol.19, No. 3, pp.275-292.

Bigliardi, B. and Bottani, E. (2010). Performance measurement in the food supply chain: a balanced scorecard approach. Facilities, Vol.28, No.5/6, pp.249-260.

Brazilian fruit. (2014). Fruticultura, available on the internet at http://brazilianfruit.org.br/ing/fruticultura/fruticultura.asp Accessed 23.09.2014.

Brewer, P.C. and Speh, T.W. (2000). Using the balanced scorecard to measure supply chain performance. Journal of Business Logistics, Vol. 21, No. 1, pp.75-93.

Cabral, R.M. (2011). Custos de transação. In: Callado, A.A.C. (Org). Agronegócio. 3ed. São Paulo: Atlas, 105-119.

Callado, A.A.C. (2015). Mensuração do desempenho de cadeias produtivas agroindustriais. In: Callado, A.A.C. (Org). Agronegócio. 4ed. São Paulo: Atlas, pp.153-162.

Callado, A.A.C., Mendes, E. and Callado, A.L.C. (2013). Um estudo empírico da significância das relações entre a elaboração de metas estratégicas e o uso de indicadores de desempenho. Revista Iberoamericana de Contabilidade de Gestión, Vol. 11, No. 21, pp.1-15. 
Chan, F.T.S. and Qi, H.J. (2003). An innovative performance measurement method for supply chain management. Supply Chain Management: An International Journal, Vol.8, No. 3, pp.209-223.

Chan, F.T.S., Qi, H.J., Chan, H.K., Lau, H.C.W. and Ip, R.W.L. (2003). A conceptual model of performance measurement for supply chains. Management Decision, Vol. 41, No. 7, pp.635-642.

Chang, H.H. (2009). An empirical study of evaluating supply chain management integration using the balanced scorecard in Taiwan. The Service Industries Journal, Vol.29, No. 2, pp.185-202.

Chenhall, R.H. (2005). Integrative strategic performance measurement systems, strategic alignment of manufacturing, learning and strategic outcomes: an exploratory study. Accounting, Organization and Society, Vol.30, pp.395-422.

Chia, A., Goh, M. and Hum, S. (2009). Performance measurement in supply chain entities: balanced scorecard perspective. Benchmarking: An International Journal, Vol.16, No. 5, pp.605-620.

Chow, G., Heaver, T.D. and Henriksson, L.E. (1994). Logistics Performance: Definition and Measurement. International Journal of Physical Distribution \& Logistics Management, Vol. 24, No. 1, pp.17-28. 
Christopher, M., (2005). Logistics and Supply Chain Management. Prentice Hall, London.

Cox, A. and Chicksand, D. (2005). The limits of lean management thinking: multiple retailers and food and farming supply chains. European Management Journal, Vol. 23, No. 6, pp.648-662.

Cox, A. and Chicksand, D. (2007). Are Win-wins Feasible? Power Relationships in Agrifood Supply Chains and Markets. In: D. Burch \& G. Lawrence, Supermarkets and agrifood supply chains: transformation in the production and consumption of foods (pp. 7499). Cheltenham: Edward Elgar.

Chenhall, R. H. (2005). Integrative strategic performance measurement systems, strategic alignment of manufacturing, learning and strategic outcomes: an exploratory study. Accounting, Organizations and Society, Vol.30, No. 5, pp.395-422.

Dubois, A., Hukthén, K. and Pedersen, A-C. (2004). Supply chains and interdependence: a theoretical analysis. Journal of Purchasing \& Supply Management, Vol10, pp.3-9.

Elrod, C., Murray, C. and Bande, S. (2013). A review of performance metrics for supply chain management. Engineering Management Journal, Vol. 2, No. 3, pp.39-50.

Estampe, D., Lamouri, S., Paris, J-L. and Brahim-Djelloul, S. (2013). A framework for analysing supply chain performance evaluation models. International Journal of Production Economics. Vol. 142, pp.247-258. 
FAO - Food and Agriculture Organization. (2013). FAO Statistical yearbook. World Food and Agriculture, available on the internet at http://issuu.com/faooftheun/docs/syb2013issuu/156 Accessed 25.09.2014.

Fauske, H., Kolberg, M., Dreyer, H. and Bolseth, S. (2007). Criteria for supply chain performance measurement systems. Proceedings of the 14th International EurOMA Conference, Ankara, Turkey, 17-20, June.

Fawcett, S.E. and Magnan, G.M. (2002). The rhetoric and reality of supply chain integration. International Journal of Physical Distribution \& Logistics Management, Vol. 32, No. 5, pp.339-361.

Folan, P. and Browne, J. (2005). A review of performance measurement: Towards performance management. Computers in Industry, Vol.56, pp.663-680.

Ganga, G.M.D. and Carpinetti, L.C.R. (2011). A fuzzy logic approach to supply chain performance management. International Journal of Production Economics, Vol.134, pp.177-187.

Gunasekaran, A; Patel, C. and McGaughey, R.E. (2004). A framework for supply chain performance measurement. International Journal of Production Economics, vol.87, No. 3, pp.333-347. 
Gunasekaran, A., Patel, C. and Tirtiroglu, E. (2001). Performance measures and metrics in a supply chain environment. International Journal of Operations \& Production Management, Vol. 2, No. 1/2, pp.71-87.

Haan, J. de., Groot, G. de., Loo, E. and Ypenburg, M. (2003). Flows of goods or supply chains: lessons from the natural rubber industry in Kerala, India. International Journal of Production Economics, Vol.81-82, pp.185-194.

Hall, Richard H. (1984). Organizações: Estruturas e Processos. 3ed. São Paulo: Editora Prentice-Hall.

Henson, S. and Reardon, T. (2005). Private agri-food standards: Implications for food policy and the agri-food system. Food Policy, Vol.30, pp.241-253.

Hingley, M. K. (2005). Power imbalance in UK agri-food supply channels: learning to live with the supermarkets? Journal of Marketing Management, Vol.21, No.1-2, pp.63-68.

Hofman, D. (2004). The hierarchy of supply chain metrics. Supply Chain Management Review, Vol.8, No. 6, pp.28-37.

Holmberg, S., (2000). A systems perspective on supply chain measurements. International Journal of Physical Distribution and Logistics, Vol.30, No. 10, pp.847-868. 
Jack, L., Ramon-Jeronimo, J. and Florez-Lopez, R., (2012). Performance measurement and risk management in intermediary food supply chain businesses. Technical Report. Chartered Institute of Management Accountants, London.

Kleijnen, J.P.C. and Smits, M.T. (2003). Performance metrics in supply chain management. Journal of Operational Research Society, Vol.54, pp.507-514.

Kolehmainen, K. (2010). Dynamic strategic performance measurement systems: balancing empowerment and alignment, Long Range Planning, Vol.43, pp.527-554.

Lambert, D.M. and Pohlen, T.L. (2001). Supply chain metrics. The International Journal of Logistics Management, Vol.12, No. 1, pp.1-19.

Lee, C.W., Kwon, I.G. and Severance, D. (2007). Relationship between supply chain performance and degree of linkage among supplier, internal integration, and customer. Supply Chain Management: An International Journal. Vol.12, No. 6, pp.444-452.

Lohman, C., Fortuin, L. and Wouters, M. (2004). Designing a performance measurement system: a case study. European Journal of Operational Research, Vol.156, pp.267-286.

McCornmack, K., Ladeira, M.B.and Oliveira, M.P.V. de., (2008). Supply chain maturity and performance in Brazil. Supply Chain Management: An International Journal, Vol.13, No. 4, pp.272-282.

Michele, P. Manzoni, J-F. (2010) Strategic performance measurement: benefits, limitations and paradoxes. Long range planning. Vol.43, No 4, pp.465-476 
MAPA - Ministério da Agricultura, Pecuária e Abastecimento. (2007). Cadeia produtiva de frutas. Buainain, A.M., and Batalha, M.O. (Org.), Série Agronegócios, 7, available on the internet

at http://www.ibraf.org.br/x_files/Documentos/Cadeia_Produtiva_de_Frutas_S\%C3\%A9rie Agroneg\%C3\%B3cios_MAPA.pdf Accessed 23.09.2014.

Matopoulos, A., Vlachopoulou, M., Folinas, D. and Manthou, V. (2004). Information architecture framework for agri-food networks. In: Bremmers, H., Omta, S.W.F., Trienekens, J.H., Wubben, E.F.M. (Eds), Proceedings of the 6th International Conference on Chain and Network Management in Agribusiness and the Food Industry 27-28, May, Ede.

Melnyk, S.A., Stewart, D.M. and Swink, M. (2004). Metrics and performance measurement in operations management: dealing with the metrics maze. Journal of Operations Management, Vol.22, pp.209-217.

Mentzer, J.T., De Witt, W., Keebler, J.S., Min, S., Nix, N.W., Smith, C.D. and Zacharia, Z.D. (2001). Defining supply chain management. Journal of Business Logistics, Vol.22, No. 2, pp.1-25.

Min, S., Mentzer, J.T. and Ladd, R.T. (2007). A market orientation in supply chain management. Journal of the Academy of Market Sciences, Vol.35, No. 4, pp.507-522. 
Morash, E. A. (2002). Supply chain strategies, capabilities and performance. Transportation Journal, Vol.41, No. 11, pp.37-54.

Neely, A., Gregory, M.and Platts, K. (1995). Performance Measurement System Design: a literature review and research agenda. International Journal of Operations \& Production Management, Vol.15, No. 4, pp.80-116.

Neves, M.F. (2003). Canais de distribuição no agronegócio: conceitos básicos. In: Neves, M.F. \& Castro, L.T. (Org.) Marketing e estratégia em agronegócios e alimentos. São Paulo: Atlas, pp.223-249.

Oliveira, T.B.A., Bornia, A.C., Silveira, S. D.F.R., Drumond, A.M. and Oliveira, M.W. (2014). Análise de custos e eficiência de fazendas produtoras de cana-de-açucar por meio da análise evolutória de dados. Custos e @ gronegócio on line, Vol.10, No. 1, pp.228-252.

Papadakis, V. M., Lioukas, S. and Chambers, D. (1998). Strategic decision-making processes: the role of management and context. Strategic Management Journal, Vol.19, No. 2, pp.115-147.

Park, J.H., Lee, J.K. and Yoo, J.S., (2005). A framework for designing the balanced supply chain scorecard. European Journal of Information Systems, Vol.14, pp.335-346.

Pelegrini, D.F., Shili, S. de F.N. and Shiki, S. (2015). Uma abordagem teórica sobre cooperativismo e associativismo no Brasil. Extensio: Revista Eletrônica de Extensão, Vol.12, No. 19, pp.70-85. 
Prieto, V.C.; Pereira, F.L.A., Carvalho, M.M. de and Laurindo, F.J.B. (2006). Fatores críticos na implementação do Balanced Scorecard. Gestão \& Produção, Vol.13, No. 1,pp. $81-92$.

Rafele, C. (2004). Logistic service measurement: A reference framework. Journal of Manufacturing Technology Management, Vol.15, No. 3, pp.280-290.

Shi, R, Zhang, J. and Ru, J. (2013). Impacts of power structure on supply chains with uncertain demand. Production and Operation Management, Vol.22, No. 5, pp.1233-1249.

Schloetzer, J. D. (2012). Process integration and information sharing in supply chains. The Accounting Review, Vol.87, No. 3, pp.1005-1032.

Spekman, R.E., Kamauff Jr., J. W. and Myhr, N. (1998). An empirical investigation into supply chain management: a perspective on partnership. Supply chain Management, Vol.3, No. 2, pp.53-67.

Teeratansirikool, L., Siengthai, S., Badir, Y. and Charoenngam, C. (2013). Competitive strategies and firm performance: the mediating role of performance measurement. International Journal of Productivity and Performance Management, Vol. 62, No. 2, pp.168-184.

Vachon, S., Halley, A. and Beaulieu, M. (2009). Aligning competitive priorities in the supply chain: the role of interactions with suppliers. International Journal of Operations \& Production Management, Vol.29, No. 4, pp.322-340. 
Van der Vorst, J.G.A.J. (2006). Performance measurement in agri-food supply chain networks. In: Ondersteijn, C.M.D., Wijnands, J.H.M., Huirne, B.M. and Van Kooten, O. Quantifying the agri-food supply chain. Springer.

Van Hoek, R.I., (1998). "Measuring the unmeasurable" - measuring and improving performance in the supply chain. Supply Chain Management, Vol. 3, No. 4, pp.187-192.

Varma, S., Wadhwa, S. and Deshmukh, S.G. (2008). Evaluating petroleum supply chain performance: application of analytical hierarchy process to balanced scorecard. Asian Pacific Journal of Marketing and Logistics, Vol.20, No. 3, pp.343-356.

Yu, M. and Nagurney, A. (2013). Competitive food supply chain networks with application to fresh produce. European Journal of Operations Research, Vol.224, No. 2, pp.273-282.

Williamson, O.E. (1975). Markets and Hierarchies: Analysis and antitrust implications. New York: Free press.

Wouters, M. And Wilderom, C. (2008). Developing performance-measurement systems as enabling formalization: A longitudinal field study of a logistics department. Accounting, Organizations and Society, Vol. 33, No. 4, pp.488-516.

Wu, I., Chang, C., (2012). Using the balanced scorecard in assessing the performance of eSCM diffusion: a multi-stage perspective. Decisions Support Systems, Vol.52, pp.474-485. 
Zhao, Y. (2002). The impact of information sharing on supply chain performance. $P h D$ Dissertation. Northwestern University. 